\title{
EFFECTS OF NaCI ON PLANT GROWTH AND ANTIOXIDANT ACTIVITIES IN FENUGREEK (Trigonella foenum graecum $\mathrm{L}$. )
}

\author{
EFEITOS DO NaCl NO CRESCIMENTO DE PLANTAS E ATIVIDADES \\ ANTIOXIDANTES EM FENO-GREGO (Trigonella foenum graecum 1.)
}

\author{
Baatour OLFA $^{1}$; Zaghdoudi MAHA ${ }^{1}$; Bensalem NADA ${ }^{1}$; Ouerghi Abidi ZEINEB ${ }^{1}$ \\ 1. Unité de Physiologie et Biochimie de la Réponse des Plantes aux contraintes Abiotiques, Département de Biologie, Faculté des \\ Sciences de Tunis El Manar, Campus Universitaire, 2092 Tunis, Tunisie. zaghdoudimaha@ yahoo.fr
}

\begin{abstract}
Fenugreek is used as a spice, vegetable and a important medicinal crops cultivated throughout the world. Since antioxidant properties have been linked to health benefits of natural products, such properties were studied salt concentrations $(0,50,100,150$ and $200 \mathrm{mM} \mathrm{NaCl})$ effect on plant growth mineral contents composition, antioxidant responses and phenolilc contents. Results showed a reduction of dry weights of leaves stems and roots growth. These changes were associated with decreased in water content, $\mathrm{K}^{+}$and $\mathrm{Ca}^{2+}$ concentrations and a highly increased in $\mathrm{Na}^{+}$and $\mathrm{Cl}^{-}$ contents in different organs. Catalase, guaiacol peroxidase activities and total phenolic content significantly increased in fenugreek leaves. Data reported here revealed the variation of phenolic compound contents at different organs in the presence of salt, who suggested the use of Fenugreek in commercial and economic applications.
\end{abstract}

KEYWORDS: Fenugreek. Salinity. Antioxidant. Polyphenols.

\section{INTRODUCTION}

In order to meet the increasing demand for medicinal plants, for the indigenous systems of medicine as well as for the pharmaceutical industry, many medicinal plants need to be cultivated commercially, but soil salinity and other forms of pollutions represent serious threats to plant production (QURESHI et al. 2005). In this context, fenugreek (Trigonella foenum graecum L.), an annual herb belonging to family Fabaceae, is extensively cultivated in most regions of the world for its medicinal value Moradi, 2013.

In many countries, this species is grown in arid and semi-arid regions where high concentration of salts is an important characteristic of the soils (MORADI, 2013). Soil salinity is one of the major abiotic stresses which affect seeds germination (MISRA; DWIVEDI, 2004), and cause several problems for plant growth (DEMIRAL; TURKAN, 2006). Although salt stress affects all growth stages of a plant, seed germination and seedling growth stages are known to be more sensitive for most plant species (CUARTERO et al., 2006)

The salinity, or drought stress, causes a serious secondary effect on cells. The effects can be direct, as the decreased CO2 availability (CHAVES et al., 2009), alterations on photosynthetic metabolism (PINHEIRO et al., 2011), or they can arise as secondary effects, such as oxidative stress and the associated synthesis of ROS as well as changes in enzyme and antioxidant metabolism. Whether ROS would act as signaling molecules or might cause oxidative stress to the tissues depend on the refined balance between ROS production, and their scavenging. Satisfactory scavenging of ROS produced at the same time in environmental stresses depends on the action of several non enzymatic as well as enzymatic antioxidants in the tissues (SHARMA et al., 2012).

Antioxidant enzymes play a key role in plant antioxidative stress (ESFANDIARI et al. 2007). Some study results showed that both nonenzymatic and enzymatic antioxidant mechanisms responded clearly to temperature and salinity stress, suggesting divergent response mechanisms (NAGESH BABU; DEVARAJ, 2008). The activities of antioxidant enzymes increased plant resistance to salinity, which depends heavily on the plant species and growth stage (ZHANG et al. 2016).

The phenolic (non-enzymatic antioxidant) compounds actively participate in the plant interactions with its environment in the sense that they allow it to respond to various biotic and abiotic stresses. These phenolic compounds play an important role in the adsorption and neutralization of free radicals, singlet oxygen, or the peroxide decomposition (KSOURI et al. 2007).

The fenugreek is known traditionally for its therapeutical and medicinal value, because of its richness in secondary metabolites that may be its means of defence against biotic and/or abiotic. However, the salinity may influence the yield of these crops by two opposite effects, increasing the concentration of these metabolites in tissues, on the 
one hand, and/or reducing their biomass production on the other hand (DE ABREU; MAZZAFERA, 2005).

Thus the salt-stressed plants may represent potential resources of polyphenols, increasing the concentration of these latter in tissues. Nowadays, we give an increasing interest to the identification and recovery of natural antioxidants of the plant origin. Consumers pay more attention to a healthy and balanced diet, relying heavily on the use of natural preservatives (RAGHAVAN, 2007). Therefore, we can hypothesize that the optimal performance of polyphenols would be obtained by using stress-tolerant species (DE ABREU AND MAZZAFERA, 2005).

This work was conducted to elucidate the effects of increasing salinity concentrations on physiological, antioxidant activity, composition phenolic. The aim of this paper was to determine the limits of fenugreek tolerance at high salinity concentration.

\section{MATERIAL AND METHODS}

\section{Plant materials and treatments}

Seeds of fenugreek (Trigonella foenumgraecum $L$ ) were sterilized with sodium hypochlorite and rinsed thoroughly with tap water and then with distilled water. To evaluate the effect of $\mathrm{NaCl}$ on fenugreek, the seeds sown in Petri dishes with wet filter paper for germination in the dark at $25^{\circ} \mathrm{C}$. Five days after germination; seedlings were transferred into pots containing nutrient solution of Hoagland and Arnon (1940) in a growth room. Photoperiod was $16 \mathrm{~h}$ with $150 \mu \mathrm{mol} \mathrm{m}-2 \mathrm{~s}-1$ PAR at the plant level. Day and night temperature and relative humidity regimes were $22 / 18^{\circ} \mathrm{C}$ and $60 / 80 \%$, respectively. Fifteen days after germination, an initial harvest was performed. Then, five treatments were started. In the first, seedlings were cultivated in the same nutrient solution and considered as control. In the other treatment, 50, 100, 150 and $200 \mathrm{mM} \mathrm{NaCl}$ was added to the medium. The final harvest was performed after 10 days of treatment. For each treatment, 8 plants were taken and the fresh weights of leaves (leave order 4), stems and roots were weighed. The samples were then ovendried at $70^{\circ} \mathrm{C}$ for $72 \mathrm{~h}$ for the determination of DW (DANESHMAND et al. 2010). Besides, fresh samples from each plant were immediately frozen in liquid nitrogen and stored at $-80^{\circ} \mathrm{C}$ until performing biochemical analysis.

\section{Ions Content}

Main ions were extracted from $25 \mathrm{mg}$ samples of dried and ground organs in nitric acid 0.1 $\mathrm{N}$. Then, $\mathrm{K}^{+}$and $\mathrm{Na}^{+}$were assayed by flame emission photometry (Jenway, PFP-7, UK) and $\mathrm{Ca}^{2+}$ and $\mathrm{Mg}^{2+}$ contents were measured by atomic absorption spectrophotometry (Varian, SpectrAA 220FS, Mulgrave, Australia). For anions, chloride was determined by coulometry (Butcher Cotlove). All mineral analyses were performed on $\mathrm{HNO} 3$ extracts.

\section{Phenolic Compounds Analysis}

Leaves were dried in a dark and aerated room with a temperature of $25-30{ }^{\circ} \mathrm{C}$, for two weeks. Acetonic leaf extracts, used to determine the polyphenol content and antioxidant activities, were obtained by magnetic stirring for $30 \mathrm{~min}$ of $1 \mathrm{~g}$ dry organ powder with $10 \mathrm{ml}$ Acetone $80 \%$. Extracts were kept at $4^{\circ} \mathrm{C}$ for $24 \mathrm{~h}$ and filtered through Whatman filter paper. This final solution was stored at $4^{\circ} \mathrm{C}$ and used to determine phenolic, flavonoid and tannin contents and to estimate non-enzymatic antioxidant activities (total antioxidant activity and Scavenging ability of DPPH radical).

\section{Total phenolic content}

Total phenolics were assayed using the Folin-Ciocalteu reagent, following Singleton et al. (1999) method; the method was based on the reduction of a phosphowolframatephosphomolybdate complex by phenolics to blue reaction products and slightly modified by Dewanto et al. (2002). An aliquot of $125 \mu \mathrm{l}$ of diluted extract $(20 \% \quad(\mathrm{v} / \mathrm{v}))$ was added to $500 \mu \mathrm{l}$ of deionized water and $125 \mu \mathrm{l}$ of F-C reagent. After shaking, the mixture was incubated for $3 \mathrm{~min}$ at room temperature. Then, $1250 \mu \mathrm{l}$ of $7 \% \mathrm{Na}_{2} \mathrm{CO}_{3}$ solution was added. The volume obtained was adjusted to $3 \mathrm{ml}$ using distilled water, mixed vigorously, and held for $90 \mathrm{~min}$ at ambient temperature. The absorbance of the solution was then measured at $760 \mathrm{~nm}$ against a blank. The sample was analysed in triplicate and the total phenolic content was expressed as mg of gallic acid equivalents (GAE) per gram of dry weight through a calibration curve range of 50 to $400 \mu \mathrm{g}$ ml-1(R2 $=0.99$ ).

\section{Flavonoid Quantification}

Total flavonoids were measured using a colorimetric assay developed by Dewanto et al. (2002) An aliquot of diluted sample of leaf extract or standard solution of (+)-catechin was added to $75 \mu \mathrm{L} \mathrm{NaNO}{ }_{2}$ solution (70 g l-1) and mixed for 6 min, before adding $0.15 \mathrm{ml} \mathrm{AlCl} 3$ (100 g L-1). 
After $5 \mathrm{~min}, 0.5 \mathrm{ml}$ of $1 \mathrm{~mol} \mathrm{L-1} \mathrm{NaOH}$ solution was added. The final volume was adjusted to 2.5 $\mathrm{ml}$, thoroughly mixed, and the absorbance of the mixture was determined at $510 \mathrm{~nm}$. Total flavonoids were expressed as grams of (+)-catechin equivalent per kilogram dry weight (g CE kg-1 DW), through the calibration curve of (+)-catechin $(50-500 \mathrm{mg}$ $\mathrm{ml})$. All samples were analysed in three replications.

\section{Tanin Quantification}

$0.05 \mathrm{ml}$ of fenugreek samples extracted in non diluted acetone was added to $3 \mathrm{ml}$ of vanilline (4\%), and $1.5 \mathrm{ml}$ of concentrated $\mathrm{H}_{2} \mathrm{SO}_{4}$. Absorbance of resulting pink-coloured solution was read at $500 \mathrm{~nm}$ against extract solvent as a blank (ZHISHEN et al. 1999). The amount of total condensed tannins is expressed as $\mathrm{mg}(+)$-catechin /g DW.

The calibration curve range was 0 à 500 $\mu \mathrm{g} . \mathrm{ml}^{-1}$ de catéchine $(\mathrm{R} 2=0.99)$. All samples were analysed in three replications.

\section{Total protein extraction and enzyme assays}

Leaves from separate plants were ground in a mortar with liquid nitrogen, and the powder was mixed with $50 \mathrm{mmol}^{-1}$ of $\mathrm{pH} 7.5$ phosphate buffer containing $1 \mathrm{mmol} \mathrm{l}^{-1}$ EDTA, $1 \mathrm{mmol} \mathrm{l}^{-1}$ dithiothreitol (DTT), 50 $\mathrm{ml} \mathrm{l}^{-1}$ glycerol and $50 \mathrm{~g} \mathrm{l}^{-1}$ polyvinylpyrrolidone (PVP), and centrifuged (15 $\left.000 \times g, 4^{\circ} \mathrm{C}, 20 \mathrm{~min}\right)$. After extraction, protein concentration was determined according to Bradford (Catalase (EC 1.111.1.6) activity was measured according to the modified method of Chance and Maehly.24 The reaction mixture consisted of 25 mmol $\mathrm{l}^{-1}$ potassium phosphate buffer ( $\left.\mathrm{pH} 7.0\right), 30$ mmol $1^{-1} \quad \mathrm{H}_{2} \mathrm{O}_{2}$ and enzyme extract. The decomposition of $\mathrm{H}_{2} \mathrm{O}_{2}$ was followed by measuring the decrease in absorbance at $240 \mathrm{~nm}$. Total peroxidase activity (EC 1.111.1.7) was assayed using guaiacol as an electron donor, with a reaction mixture containing $50 \mathrm{mmol} \mathrm{l}^{-1}$ potassium phosphate (pH 7.0), $0.1 \mathrm{mmol}^{-1}$ EDTA, $5 \mathrm{mmol} \mathrm{l}^{-1}$ $\mathrm{H}_{2} \mathrm{O}_{2}$ and $10 \mathrm{mmol} \mathrm{l}^{-1}$ guaiacol $-\mathrm{a}$ method derived from Fielding and Hall (1978). The increase of absorbance, due to tetraguaiacol formation, was recorded at $470 \mathrm{~nm}$.

\section{Evaluation of total antioxidant capacity}

The assay is based on the reduction of Mo (VI) to Mo (V) by the extract and subsequent formation of a green phosphate/Mo (V) complex at acid pH (PRIETO et al. 1999). An aliquot of sample extract was combined in an eppendorf tube with 1 $\mathrm{ml}$ of reagent solution $(0.6 \mathrm{M}$ sulfuric acid, $28 \mathrm{mM}$ sodium phosphate, and $4 \mathrm{mM}$ ammonium molybdate). The tubes were incubated in a thermal block at $95 \mathrm{C}$ for $90 \mathrm{~min}$. After the mixture had cooled to room temperature, the absorbance of each solution was measured at $695 \mathrm{~nm}$ (Anthelie Advanced 2, SECOMAN) against a blank. The antioxidant capacity was expressed as mg gallic acid equivalent per gram of dry weight (mg GAE/g DW). All samples were analyzed in three replications.

\section{RESULTS}

\section{Plant aspect, Growth and relative water contents}

The growth responses to salt stress of fenugreek were represented in Figure 1. The biomass accumulation of fenugreek was impaired by $\mathrm{NaCl}$, a few days after salt treatment was started; wish yellow colouration of young leaves (revealed incipient necrosis). For shoots, biomass production decreased by $10 \%$ in comparison to control after 10 days of $\mathrm{NaCl}$ treatment (Figure 1). This response was accompanied by a diminution of the leaf number mainly associated with a reduction of total leaf area, (Table 1) and gradual diminution total leaf surface area by $60 \%$ at $\mathrm{NaCl} 200 \mathrm{mM}$. Nevertheless, the effect of salt on biomass was also important in roots than leaves and less pronounced in stems. In addition, the applied $\mathrm{NaCl}$ inhibit the growth of fenugreek plant.

Water content of three organs of fenugreek (Figure. 2) depended poorly on $\mathrm{NaCl}$ treatments. At $50 \mathrm{mM}$, salt treatment induced no significant effect on stems and roots tissue hydration in fenugreek, but increased it (by $30 \%$ ) in leaves. At higher $\mathrm{NaCl}$ concentration $(200 \mathrm{mM}$ $\mathrm{NaCl}$ ), water content decreases significantly at different organs, but it's were more pronounced in roots (Figure. 2).

The water content of stems is was higher than leaves and roots in the presence and absence of salt. Other parameters can be used to express the effect of $\mathrm{NaCl}$ on the growth of fenugreek plants, such as the sensitivity index SI, calculated from the production of dry material are shown in Table 1. 

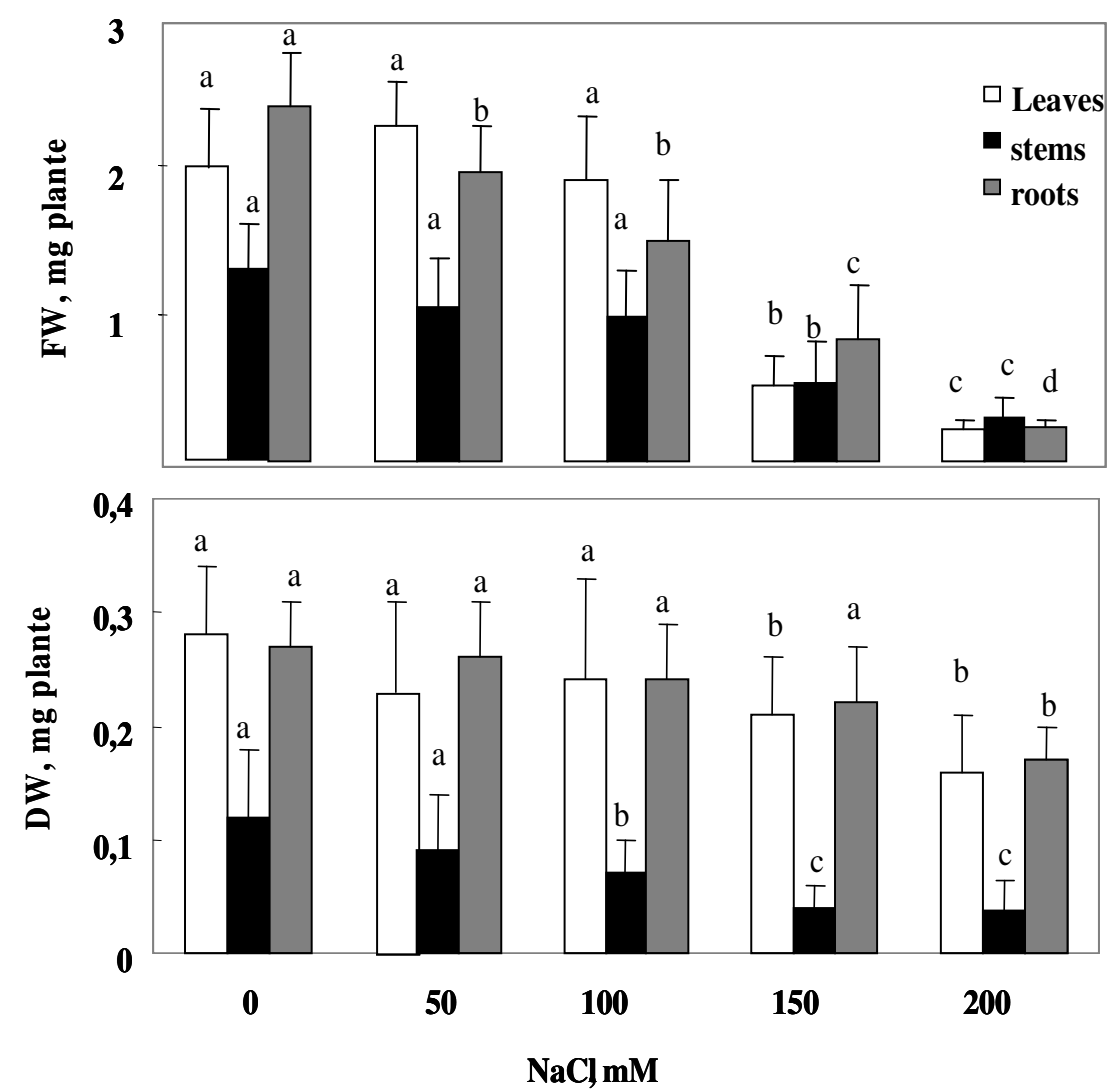

Figure 1: Fresh weights (FW) and Dry weights (DW) in leaves, stems, and roots Fenugreek plants after 10 days of growth under $\mathrm{NaCl}(0,50,100,150$ et $200 \mathrm{mM} \mathrm{NaCl})$ conditions. Average of 8 repetitions and confidence intervals at $5 \%$.

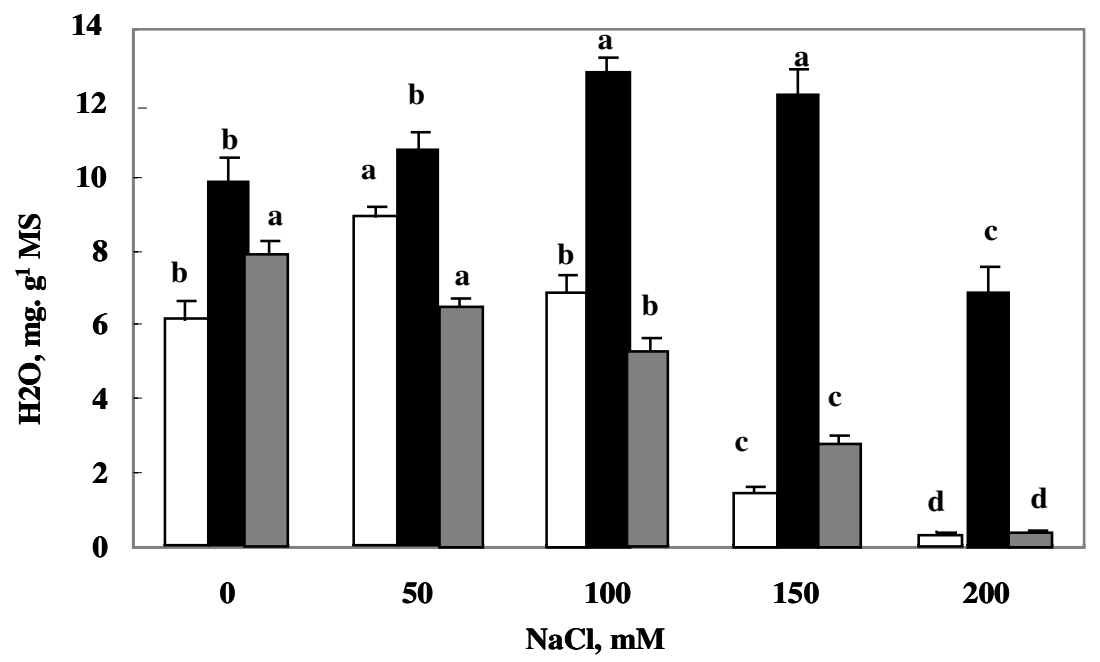

Figure 2: Effect of $\mathrm{NaCl}$ on tissue hydration in leaves, stems, and roots fenugreek plants after 10 days of growth under $\mathrm{NaCl}(0,50,100,150$ and $200 \mathrm{mM} \mathrm{NaCl})$ conditions. Average of 8 repetitions and confidence intervals at $5 \%$. 
Table 1: Effect of increasing $\mathrm{NaCl}$ concentration in leaves of Trigonella foenum-graecum on the leaf surface and the total number of plant leaves of fenugreek. The culture duration is 10 days in absence or presence of 50, 100,150 and $200 \mathrm{mM} \mathrm{NaCl}$. Average of 6 repetitions. Safety interval at 5\%.

\begin{tabular}{|c|c|c|c|c|c|c|}
\hline $\mathrm{NaCl} \mathrm{mM}$ & 0 & 50 & 100 & & 150 & 200 \\
\hline Total leaf surface area & $19,75 \pm 3.46^{a}$ & $19,03 \pm 3.33 \mathrm{a}$ & $14,09 \pm 3.55$ & $b$ & $10,83 \pm 2.15 c$ & $7,79 \pm 1.49$ \\
\hline Individual leaf surface area & $0,49 \pm 0.07 \mathrm{a}$ & $0,51 \pm 0.06 \quad a$ & $0,48 \pm 0.03$ & $\mathrm{a}$ & $0,41 \pm 0.02 \quad b$ & $0,4 \pm 0.05$ \\
\hline Leaf number & $41,3 \pm 9 \quad a$ & $38,5 \pm 10 \quad b$ & $30,9 \pm 9$ & c & $26,8 \pm 6.4 \quad d$ & $19,9 \pm 4$ \\
\hline
\end{tabular}

\section{Ion accumulation}

Salt stress causes disturbances in the mineral nutrition of fenugreek plants. In the presence of $\mathrm{NaCl}$, the amounts of $\mathrm{K}^{+}$and $\mathrm{Ca}^{2+}$ absorbed by roots and transported to the shoots were decreased significantly with the increasing of salinity levels , (exceptly of steems) stricted significantly.
$\mathrm{Na}^{+}$and $\mathrm{Cl}^{-}$concentrations in the tissues increased with different $\mathrm{NaCl}$ concentration, (Figure 3). The $\mathrm{Na}^{+}$and $\mathrm{Cl}^{-}$accumulation was clearly increased as when $\mathrm{NaCl}$ concentration was increased from 0 to $200 \mathrm{mM}$, in the different organs. As similarly to $\mathrm{Cl}^{-}$accumulation, $\mathrm{Na}^{+}$ reaches very high values at of $200 \mathrm{mM} \mathrm{NaCl}$ : 4.45; 4.01 and 5.59 méq.g $\mathrm{DW}^{-1}$, respectively, in the leaves, stems and roots.

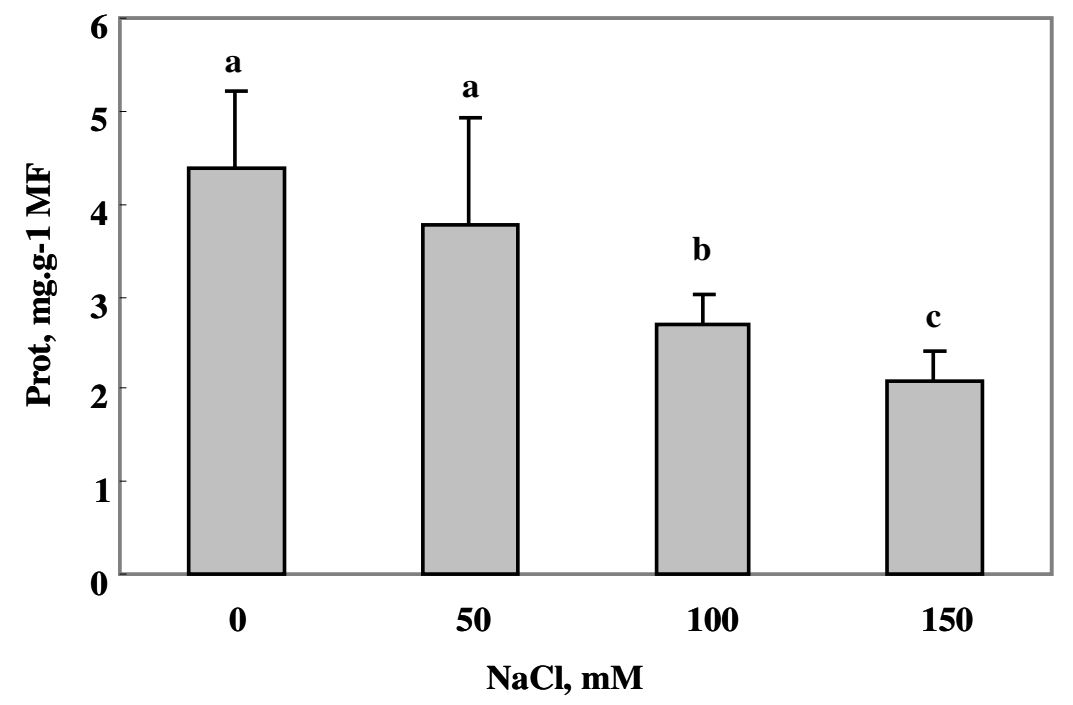

Figure 3: $\mathrm{Na}^{+}, \mathrm{Cl}^{-}{ }^{-} \mathrm{K}^{+}$and $\mathrm{Ca}^{2+}$ content in leave, stem, and roots fenugreek plants after 10 days of growth under $\mathrm{NaCl}(0,50,100,150$ and $200 \mathrm{mM} \mathrm{NaCl})$ conditions. Average of 8 repetitions and confidence intervals at $5 \%$.

\section{The soluble proteins}

Protein contents in the leaves of fenugreek plant after 10 day of $\mathrm{NaCl}$ treatment are given in Figure 4. It seems that the presence of $\mathrm{NaCl}$ salt in the nutrient solution did not affect proteins contents at a $50 \mathrm{mM} \mathrm{NaCl}$ concentration, but was increase from $100 \mathrm{mM} \mathrm{NaCl}$, and increased by about $200 \%$ at $150 \mathrm{mM}$.

\section{Antioxidant enzyme activity}

To control the level of reactive oxygen species under stress conditions, plant tissues contain a series of enzymes scavengers of ROS. An arrangement of enzymes is needed for the regeneration of the active forms of the antioxidants; represented by both non enzymatic and enzymatic reactions (ZOROV, 2014) 

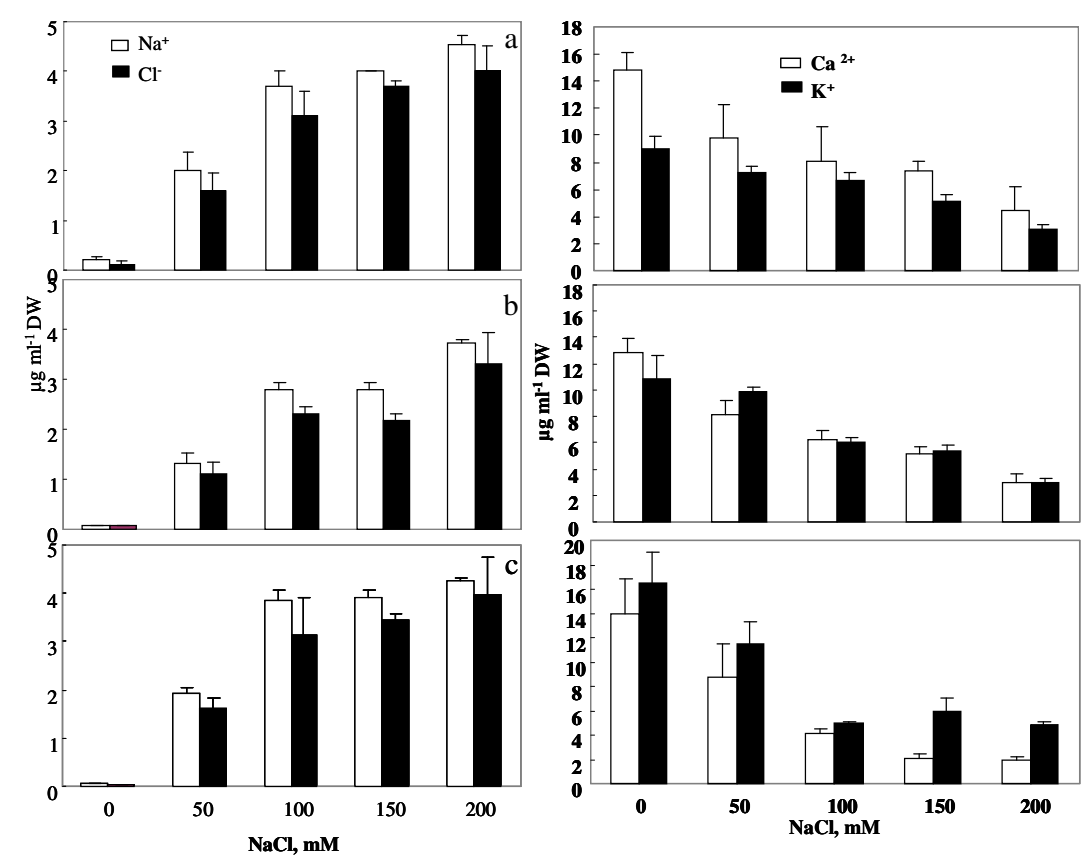

Figure 4. Effect of $\mathrm{NaCl}$ on the content of total soluble protein in fenugreek plant leaves (Trigonella foenumgraecum) local variety. Average of 8 repetitions and confidence intervals at $5 \%$.

In our study, a quantitative analysis of the activities of some antioxidant enzymes, such as guaiacol peroxidase and catalase, are also measured in order to clarify the effect of salt on the antioxidant activity of fenugreek plants grown on a medium added or not with $\mathrm{NaCl}(0,50,100$ et 150 $\mathrm{mM})$. The results are shown for the leaves in Figures 5 and 6. An increase in the activity of antioxidant enzymes at a lower salt concentration $(50 \mathrm{mM})$, as shown in Figures 6.

The GPX activity increases with the $\mathrm{NaCl}$ concentration in fenugreek leaves and reached $300 \%$ at a concentration of 100 and $150 \mathrm{mM} \mathrm{NaCl}$ as compared to control. The catalase activity in fenugreek plants, cultured in the presence and absence of salt, is shown in Figures 6. At control medium, catalase activity is of $6.77 \mathrm{~m} . \mathrm{mol} \mathrm{H}_{2} \mathrm{O}_{2}$ $\mathrm{min}^{-1}$.mg P $\mathrm{P}^{-1}$. In the presence of 100 and $150 \mathrm{mM}$ $\mathrm{NaCl}, \mathrm{CAT}$ activity in leaves respectively increases by 200 and $250 \%$ as compared to control. The salt stress induced a significant increase in the activity of enzyme of-fenugreek.

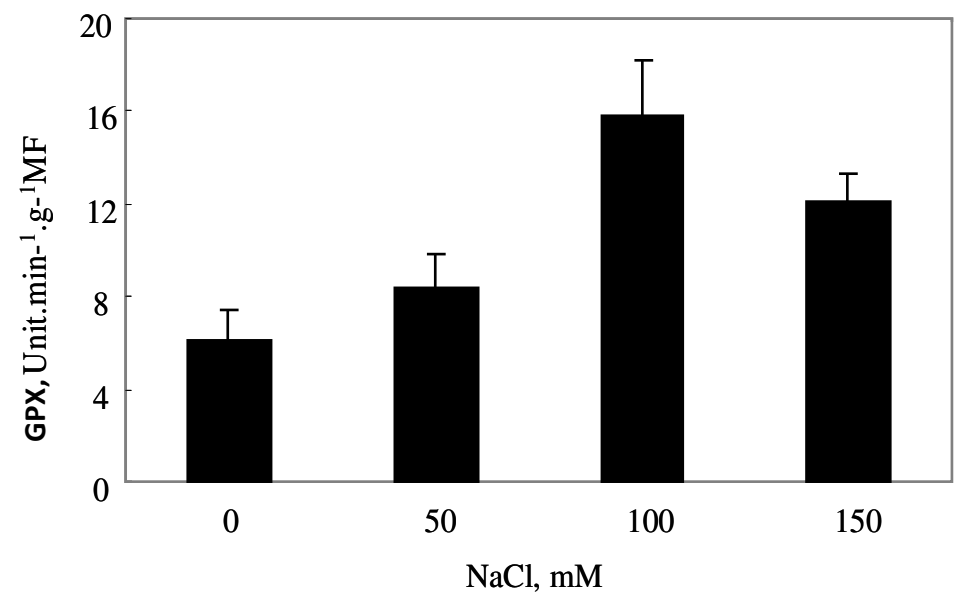

Figure 5: Effect of salt on the peroxidase activity (GPX) on the fenugreek plant leaves (Trigonella foenum graecum). Average of 6 repetitions and safety intervals of $5 \%$. 


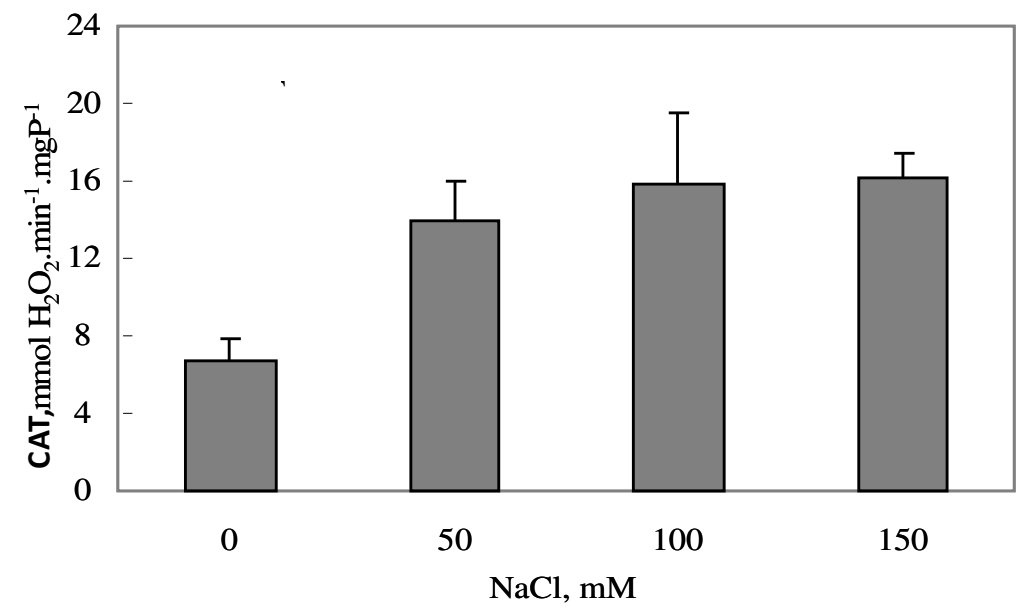

Figure 6: Effect of salt on the catalase activity on the fenugreek plant leaves (Trigonella foenum graecum). Average of 6 repetitions and safety intervals of 5\%.

\section{Assay of secondary metabolites}

\section{Total polyphenols content}

The effect of salt stress on the total polyphenol content of fenugreek leaves was shown in Table 2. Polyphenols content depend on the salt concentration. The increase of salt concentration induced a greater accumulation of polyphenols. Indeed, polyphenol contents significantely increased by 30 and $71 \%$ as compared to control.

Table 2: The effect of salt stress on the levels of total polyphenols (mg EAG.g ${ }^{-1}$ MS), flavonoids, condensed tannins (mg EC.g ${ }^{-1} \mathrm{MS}$ ) and in total antioxidant capacity of fenugreek leaves. Average of 4 repetitions and safety intervals at $5 \%$.

\begin{tabular}{lllllllllll}
\hline & $0 \mathrm{mM}$ & & $50 \mathrm{mM}$ & & 100 & $\mathrm{mM}$ & & 150 & $\mathrm{mM}$ \\
\hline Polyphenol & content & 4.58 & $\mathbf{d}$ & 8.38 & $\mathbf{c}$ & 10.7 & $\mathbf{b}$ & 12.7 & $\mathbf{a}$ \\
\hline Flavonoid content & 2.66 & $\mathbf{d}$ & 4.53 & $\mathbf{c}$ & 6.16 & $\mathbf{b}$ & 8.25 & $\mathbf{a}$ \\
\hline Tanin content & 0.84 & $\mathbf{d}$ & 1.36 & $\mathbf{c}$ & 1.66 & $\mathbf{b}$ & & 1.75 & $\mathbf{a}$ \\
\hline ATT & 21.78 & $\mathbf{c}$ & 25.06 & $\mathbf{b}$ & 25.78 & $\mathbf{b}$ & 31.06 & $\mathbf{a}$ \\
\hline
\end{tabular}

\section{Flavonoids content}

Depending on salt treatments, the changes in flavonoids levels in leaves are shown in table 2. Total flavonoids contents, expressed as mg EC.g- ${ }^{1}$ MS, are estimated on acetone extracts of fenugreek leaves. A stimulation of flavonoids content in leaves as salt concentration increases. In addition flavonoids content increased by two and three-fold respectively at 50 and $150 \mathrm{mM} \mathrm{NaCl}$ as compared to control.

\section{Condensed tannins content}

Salt addition increased the tannin content from $50 \mathrm{mM}$ of $\mathrm{NaCl}$, but increases by $200 \%$ compared to the control at $100 \mathrm{mM} \mathrm{NaCl}$ (Table 2).

\section{Estimation of total antioxidant capacity}

The total antioxidant capacity was estimated in fenugreek leaves extracts (Table 2). The results showed that salt stress induces a significant stimulation of the antioxidant capacity of leaves. 


\section{DISCUSSION}

The biomass produced by the Fenugreek, as illustrated by leaf, stem and root dry weight, was more depressed by salt in 150 and $200 \mathrm{mM}$. Growth rate is expected to be positively related with photosynthetic capacity, which itself is determined by the total leaf number and the specific photosynthetic activity of leaves. The effect of $\mathrm{NaCl}$ on the growth of the fenugreek plants is perceptible from a concentration of $100 \mathrm{mM} \mathrm{NaCl}$. This effect resulted in a decrease in plant biomass. To better enhance the effect of $\mathrm{NaCl}$ on the growth of this plant, we estimated the sensitivity index SI (Table 1). Our results suggest that the sensitivity of biomass production is mainly dependant on the growth activity during treatment. In addition negative SI negative values are observed in response to higher concentrations of $\mathrm{NaCl}(100$ and 150 $\mathrm{mM})$. The decrease in biomass depending on the severity of stress could be an adaptive strategy. Indeed, plant reduces its exchange surface with the external environment in order to conserve a better water content. In aromatic and medicinal plants, recent studies emphasized sensitivity to salt stress; illustrated by a decrease in growth, such as in Mentha pulegium (OUESLATI et al. 2010), an halophyte behavior in Sesuvium portulacastrum (MESSEDDI et al. 2004) or by a reduction in the biomass production by 25 and $38 \%$ as compared to control plants at 50 and $75 \mathrm{mM} \mathrm{NaCl}$, respectively (BEN TAARIT et al. 2010). A growth reduction by salt constraint is considered by many authors as critical parameters for discrimination between species or cultivars, tolerant and sensitive.

(TUTEJA et al., 2011). Our findings suggest that fenugreek was sensitive to salt at a moderate $\mathrm{NaCl}$ concentration $(100 \mathrm{mM} \mathrm{NaCl})$.

Increasing levels of $\mathrm{NaCl}$ induced a progressive absorption of $\mathrm{Na}^{+}$and $\mathrm{Cl}^{-}$in plant, agreeing with Turan et al. (2007a, b). Excessive $\mathrm{Na}^{+}$ concentration in the plant tissue hinders nutrient balance, and causes toxicity osmotic regulation and causes specific ion toxicity (ARZANI, 2008). When $\mathrm{NaCl}$ was applied to the soil, the levels of $\mathrm{K}^{+}$ in plant were reduced in accordance with the antagonism between $\mathrm{Na}^{+}$and $\mathrm{K}^{+}$(AZEVEDO; TABOSA, 2000). Besides, as in a Thellungiella halophila (M'RAH et al. 2006), a competition in absorption and transport of $(\mathrm{K} / \mathrm{Na})$ from the roots to aerial parts was found. According to Kaddour et al. (2009), a good selectivity for $\mathrm{K}^{+}$was necessary to maintain better plant growth on saline medium. Indeed, a law biomass production due to $\mathrm{Na}^{+}$ competition with $\mathrm{K}^{+}$for uptake and transport causes a deficiency of potassium (SHIYAB et al. 2003). Since potassium as suggested by Ashraf and Orooj (2006) and Oueslati et al. (2010) was one of the most growth-limiting factors under saline conditions. Salt stress may have either an ionic or an osmotic component in plants (TONON et al. 2004). Both could potentially be responsible for the observed physiological perturbations in fenugreek leaves. The accumulation of $\mathrm{Na}^{+}$and $\mathrm{Cl}^{-}$in leaves of glycophytes is known to impose various stressors on the cells which alter their functional state, resulting in physiological stress (GASPAR et al. 2002). When severe, these have several detrimental effects, corresponding to direct or indirect salt toxicity. As initially hypothesized by (M'RAH, 2006), in the absence of efficient internalization of the ions by leaf cells, their concentration in the leaf apoplast may reach excessive values, leading to leaf cell dehydration (MUNNS; PASSIOURA, 1984) and membrane disruption (SPEER; KAISER, 1991). Furthermore, if ions absorbed by the leaf cells are not efficiently compartmentalized in the vacuoles, $\mathrm{Na}^{+}$and $\mathrm{Ca}^{2+}$ may build to toxic levels in the cytoplasm (FLOWERS et al. 1991), and essential metabolic pathways such as photosynthesis may be inhibited (MELONI et al. 2003). Ionic and osmotic disturbances may also result in stomata closure, which limits photosynthesis (MELONI et al. 2003).

In this study, we showed that fenugreek plants exposed to $\mathrm{NaCl}$ increased the high proline (Fig 7). Also, leaves of plants exposed on salt stress have accumulated high levels of proline compared to control plants. In addition there was circumstantial evidence that the synthesis of proline dirty stress induced was an adaptive response since it can function as a non-toxic osmolyte, an osmoprotectant that occurs in the cytoplasm where it acts as a protecting of enzyme at the origin (DELAUNEY; VERMA, 1993). It is believed that this amino-acid helps in the protection of enzymes and membrane integrity in plants subject to restrictive conditions (ASHRAF; FOOLAD, 2007). However, there is evidence that proline accumulation was a symptom of salt stress-induced metabolic disorders rather than being involved in its alleviation (SILVEIRA et al. 2009). From this fact, the salinity significantly increases in proline content in different cultivars and tolerant and sensitive species, with a greater accumulation among those most tolerant (MANSOUR et al. 2005). This can be correlated to an adaptation to salt (MANSOUR et al. 2005).

Effect of salt stress on the plant tissues were determined by measuring of MDA content. Our results showed lipid peroxidation increased as the 
stress level rose up. In fact, in leaves at $150 \mathrm{mM}$ $\mathrm{NaCl}$, the MDA content was 4 fold higher than in control. The increase in MDA content was a clear indication for oxidative stress in these plants, which thus seemed to suffer from a acute saline aggression. It has been reported that MDA content was correlated with leaf $\mathrm{H}_{2} \mathrm{O}_{2}$ accumulation in two corn varieties (HAJLAOUI et al. 2009). These results were previously reported in other cultivated species (SUDHAKAR et al. 2001).

To better understand the nature of salt effect and the ability of the fenugreek plant to tolerate this abiotic stress, we were interested in studying the effect of salt stress on biochemical parameters in fenugreek. Excess of ROS causes phytotoxic reactions such as lipid peroxidation, protein degradation and DNA mutation (PITZSCHKE; HIRT, 2006). To protect themselves against these toxic oxygen intermediates, a simultaneous increase antioxidant system such as catalase and peroxidases in salt treated plants. The antioxidant system is made of a large number of enzymes and a low molecular weight compounds that important for the homeostasis of ROS (MAHMOUDI et al. 2010).

Our results show that salt treatment significantly increased CAT and GPX activities in fenugreek in the presence of 50,100 and $150 \mathrm{mM}$ $\mathrm{NaCl}$. These results are consistent with those of Meloni et al. (2002) who found among cotton cultivars a stimulation of peroxidase activity by 76 and $94 \%$ of control at 100 and $200 \mathrm{mM} \mathrm{NaCl}$. Also, the salt induced a significant increase in the guaiacol peroxidase activity in the leaves of rice plants (LEE et al. 2001). This suggests that this plant has a high capacity of $\mathrm{H}_{2} \mathrm{O}_{2}$ decomposition. The antioxidant activity increase, such as GPX, APX, and CAT is essential in this tolerance. GPX and CAT are the most effective antioxidant enzymes in plant protection against cell damage Scandalios (2005). Moreover, it was shown that CAT works with SOD to better protect plants against cell damage (SCANDALIOS, 2005). In addition, CAT and GPX are responsible for the detoxification of $\mathrm{H} 2 \mathrm{O} 2$ and they probably have the same importance at the detoxification stage in fenugreek as response to this $\mathrm{NaCl}$ concentration. These results clearly indicate the criteria role of CAT and GPX in the fenugreek plant protection against the $\mathrm{NaCl}$ toxicity.

Phenolic compounds are an important group that is widely distributed in plants; they show a wide spectrum of biological activities such as antioxidant activity, antiinflammatory effect, and anticancer effect Shao et al., 2008). The quantification of total polyphenols in fenugreek leaves was study at high $\mathrm{NaCl}$ concentration $(150 \mathrm{mM})$. As shown in table 5 a significant amount of polyphenols content $(12,7$ $\mathrm{mg}$ of $\mathrm{GAE} \mathrm{g}^{-1}$ at $150 \mathrm{mM} \mathrm{NaCl}$ ), which is about 2,5 times higher than control leaves extracts $(4.58 \mathrm{mg}$ of GAE $\mathrm{g}^{-1}$ ). Elzaawely et al. (2007) reported similar results in plant leaves of Alpinia zerumbet treated with copper sulphate, which gave them greater resistance to this salt explained by the antioxidant activity of polyphenols according to these authors.

The levels of total polyphenols were higher than those reported in some other medicinal and aromatic plants such as Nigella sativa $L$. (BOURGOU et al. 2008). In addition, our results are consistent with several studies showing an increase in the polyphenol content in salt stress (NAVARRO et al. 2006). These data suggest that the degree of the cellular oxidative damage in plants exposed to abiotic stress is controlled by the ability to protect against oxidative agents (KSOURI et al. 2007).

As for total polyphenols, salt stimulates the synthesis of flavonoids in these plants with a much stronger effect in leaves at $150 \mathrm{mM} \mathrm{NaCl}$ (table 2). According to Cushine and Lamb, (2005), flavonoids are phenolic compounds had a significant antioxidant anti-tumor and anti-microbial activity, and contribute to the prevention of cardiovascular diseases. Flavonoids are often induced by abiotic stress and have a role in plants protection (GRACE; LOGAN, 2000). Similarly, an increase in condensed tannins was observed (table 5). It is generally accepted that phenolic compounds give plants a strong antioxidant activity (JIN JUN et al. 2001). Our results confirmed that the fenugreek grown at $100 \mathrm{mM} \mathrm{NaCl}$ had a better antioxidant activity compared to other concentrations. Karray et al. (2010) showed that in Mentha pulegium, salt induces an increase in polyphenol levels in leaves and their antioxidant activity.

\section{CONCLUSION}

Fenugreek appears to be tolerant to $\mathrm{NaCl}$ $100 \mathrm{mM}$ but sensitive to $150 \mathrm{mM}$. This low sensitivity was mainly due to maintenance of biosynthetic activity, salt status, a higher phenolic concentration and stronger antioxidant activities. Finally, this survey of effect salt stress at fenugreek reveals that the intraspecific variability of biomass production was accompanied by a modest but real variability in the capacity to induce antioxidative mechanisms in response to salt stress.

\section{FUNDING}

This study was achieved in the Biology Department in the Faculty of Sciences, the 
University Campus Tunis El Manar and not funded (no subsidy)

RESUMO: O feno-grego é usado como especiaria, vegetal e uma importante cultura medicinal cultivada em todo o mundo. Como as propriedades antioxidantes têm sido associadas aos benefícios à saúde dos produtos naturais, tais propriedades foram estudadas quanto ao efeito das concentrações de sal $(0,50,100,150$ e $200 \mathrm{mM} \mathrm{de} \mathrm{NaCl}) \mathrm{no}$ crescimento das plantas, composição do conteúdo mineral, respostas antioxidantes e teores fenólicos. Os resultados mostraram uma redução do peso seco dos caules das folhas e crescimento das raízes. Essas alterações foram associadas à diminuição do conteúdo de água, concentrações de $\mathrm{K}+$ e $\mathrm{Ca} 2+$ e um aumento nos teores de $\mathrm{Na}+\mathrm{e} \mathrm{Cl}-\mathrm{em}$ diferentes órgãos. As atividades de catalase e da peroxidase do guaiacol e o teor de fenólicos totais aumentaram significativamente em folhas de feno-grego. Os dados aqui relatados revelaram a variação do conteúdo de compostos fenólicos em diferentes órgãos na presença de sal, que sugeriu o uso do feno-grego em aplicações comerciais e econômicas.

PALAVRAS-CHAVE: Feno-grego. Salinidade. Antioxidante. Polifenóis

\section{REFERENCES}

ARZANI, A. Improving salinity tolerance in crop plants: a biotechnological view. Vitro Cell. Dev. Biol. Plant, v. 44, p. 373-383, 2008. https://doi.org/10.1007/s11627-008-9157-7

ASADA, K. The water-water cycle in chloroplasts: Scavenging of active oxygens and dissipation of excess photons. Annual Reviews of Plant Physiology and Plant Molecular Biology, v. 50, p. 601-639, 2012. https://doi.org/10.1146/annurev.arplant.50.1.601

ASHRAF, M.; AND OROOJ, A. Salt stress effect on growth, ion accumulation, and seed oil concentration in an arid zone traditional medicinal plant ajwain (Trachyspermum ammi L). Arid Environment. v. 64, p. 209220, 2006. https://doi.org/10.1016/j.jaridenv.2005.04.015

ASHRAF, M.; FOOLAD, M. R. Roles of glycine betaine and proline in improving plant abiotic stress resistance. Environ. Exp. Bot., v. 59, n. 2, p. 206-216, 2007. https://doi.org/10.1016/j.envexpbot.2005.12.006

AZEVEDO, A. D.; TABOSA, J. N. Estresse salino em plantulas de milho: Parte I Analise do crescimento. Revista Brasileira de Engenharia Agricola e Ambiental, v. 1, p.1 59-164, 2000.

BATES, L. S.; WALDREN, R. P.; TEARE, I. D. Rapid determination of free proline for water-stress studies. Plant. Soil, v. 39, p. 205-207, 1973. https://doi.org/10.1007/BF00018060

BEN TAARIT, M.; MSAADA, K.; HOSNI, K. AND MARZOUK, B. Changes in fatty acid and essential oil composition of sage (Salvia officinalis L) leaves under $\mathrm{NaCl}$ stress. Ind. Crops. Prod., v. 30, p. 333-337, 2010. https://doi.org/10.1016/j.indcrop.2009.06.001

BOURGOU, S.; KSOURI, R.; BELLILA, A.; SKANDARANI, I.; FALLEH, H.; MARZOUK, B. Phenolic composition and biological activities of Tunisian Nigella sativa L. shoots and roots. C R Biol. v. 331, p. 4855, 2008. https://doi.org/10.1016/j.crvi.2007.11.001

BRADFORD, K J. Manipulation of seed water relations via osmotic priming to improve germination under stress conditions. Hortic Sci., v. 21, p. 1105-1112, 1986.

CHAVES, M. M.; FLEXAS, J; PINHEIRO, C. Photosynthesis under drought and salt stress: regulation mechanisms from whole plant to cell. Ann Bot., v. 103, p. 551- 560, 2009. https://doi.org/10.1093/aob/mcn125

CUARTERO, J.; BOLARIN, M.C.; ASINS, M. J.; MORENO, V. Increasing salt tolerance in the tomato. J. Exp. Bot., v. 57, n. 5, p. 1045-1058, 2006. https://doi.org/10.1093/jxb/erj102 
CUSHINE, T.; LAMB, A. J. Antimicrobial activity of flavonoids. Int. J. Antimicrob. Agents. v. 26, p. 343356, 2005. https://doi.org/10.1016/j.ijantimicag.2005.09.002

DANESHMAND, F.; ARVIN, M. J.; AND KALANTARI, K. M. Acetylsalicylic acid (Aspirin) induces salinity and osmotic tolerance in Solanum acaule in vitro. Agrochimica, v. 54, n. 1, p. 52-64, 2010a.

DE ABREU, I. N.; MAZZAFERA, P. Effect of water and temperature stress on the content of active constituents of Hypericum brasiliense Choisy. Plant Physiol Biochem., v. 43, p. 241-248, 2005. https://doi.org/10.1016/j.plaphy.2005.01.020

DELAUNEY, A. J.; VERMA, D. P. S. Proline biosynthesis and osmoregulation in plants. Plant. J., v. 4, p. 215-223, 1993. https://doi.org/10.1046/j.1365-313X.1993.04020215.x

DEMIRAL, T.; AND TURKAN, I. Exogenous glycine betaine affects growth and proline accumulation and retards senescence in two rice cultivars under $\mathrm{NaCl}$ stress. Environ. Exp. Bot, v. 56, p. 72-79, 2006. https://doi.org/10.1016/j.envexpbot.2005.01.005

DEWANTO, V.; WU, X.; ADOM, K. K.; LIU, R. H. Therminal processing enhances the nutritional value of tomatoes by increasing total antioxidant activity. J. Agric Food Chem., v. 50, p. 3010-3014, 2002. https://doi.org/10.1021/jf0115589

DU, Z.; BRAMLAGE, W. J. Modified thiobarbituric acid assay for measuring lipid oxidation in sugar-rich plant tissue extracts. J. Agric Food Chem., v. 40, p. 1566-1570, 1992. https://doi.org/10.1021/jf00021a018

ELZAAWELY, A. A.; XUAN, T. D.; TAWATA, S. Changes in essential oil, kava pyrones and total phenolics of Alpinia zerumbet (Pers.) B.L.Burtt. and R.M. Sm. Leaves exposed to copper sulphate. Environ. Exp. Bot, v. 59, p. 347-353, 2007. https://doi.org/10.1016/j.envexpbot.2006.04.007

FIELDING, J. L.; HALL, J. L. A biochemical and cytochemical study of peroxidise activity in roots of Pisum sativum: I. A comparison of dab-peroxidase and guaiacol peroxidase with particular emphasis on the properties of cell wall activity. J. exp. Bot. v. 29, p. 969-981, 1978.

FLOWERS, T. J.; HAJIBAGHERI, M. A.; YEO, A. R. Ion accumulation in the cell walls of rice plantsgrowing under saline conditions: evidence for the Oertli hypothesis. Plant. Cell. Environ., v. 14, p. 319-325, 1991. https://doi.org/10.1111/j.1365-3040.1991.tb01507.x

GASPAR, T.; FRANCK, T.; BISBIS, B.; KEVERS, C.; JOUVE, L.; HAUSMAN, J. F.; DOMMES, J. Concepts in plant stress physiology, Application to plant tissue cultures. Plant. Growth. Regulation., v. 37, p. 263-285, 2002. https://doi.org/10.1023/A:1020835304842

GRACE, S. C.; AND LOGAN, B. A. Energy dissipation and radical scavenging by the plant phenylpropanoid pathway. Philos Trans R. Soc. B, v. 355, p. 1499-1510, 2000.

GROSS, J. Pigments in vegetables, Chlorophus and carotenoids. Avi: Van Nostrand Reinhold Company Inc. New York, 1991. https://doi.org/10.1007/978-1-4615-2033-7

HAJLAOUI, H.; DENDEN, M.; AND EL AYEB, N. Differential responses of two maize (Zea mays L.) varieties to salt stress: changes on polyphenols composition of foliage and oxidative damages. Ind. Crops. Prod., v. 30, p. 144-151, 2009. https://doi.org/10.1016/j.indcrop.2009.03.003

JUN JIN, W.; HAN, B. K.; YU, K. W.; KIM, M. S.; CHANG, I. Antioxidant effects of Origanum majorana L. On superoxide anion radicals. Food. Chem, v. 75, p. 439-444, 2001. https://doi.org/10.1016/S03088146(01)00233-3 
KADDOUR, R.; NASRI, N.; M'RAH, S.; BERTHOMIEU, P.; LACHAAL, M. Comparative effect of potassium on $\mathrm{K}$ and Na uptake and transport in two accessions of Arabidopsis thaliana during salinity stress. C R Biologies, v. 332, p. 784-794, 2009. https://doi.org/10.1016/j.crvi.2009.05.003

KARRAY, B. N.; KSOURI, R.; FALLEH, H.; RABHI, M.; ABDUL, J. C.; GRIGNON, C.; LACHAÂL, M. Effects of Environment and Development Stage on phenolic content and antioxidant Activities of Mentha pulegium L. J. Food. Biochem. v. 34, p. 79-89, 2010. https://doi.org/10.1111/j.1745-4514.2009.00303.x

KSOURI, R.; MEGDICHE, W.; DEBEZ, A.; FALLEH, H.; GRIGNON, C.; ABDELLY, C. Salinity effects on polyphenol content and antioxidant activities in leaves of the halophyte Cakile maritime. Plant. Physiol. Biochem., v. 45, p. 244-249, 2007. https://doi.org/10.1016/j.plaphy.2007.02.001

LEE, D. H.; KIM, Y. S.; AND LEE, C. B. The inductive responses of the antioxydant enzymes by salt stress in the rice (Orysa sativa L.). J. Plant. Physiol., v. 158, p. 737-745, 2001. https://doi.org/10.1078/0176-161700174

M'RAH, S.; OUERGHI, Z.; BERTHOMIEU, C.; HAVAUX, M.; JUNGAS, C.; HAJJI, M.; GRIGNON, C.; LACHAÂL, M. Effects of $\mathrm{NaCl}$ on the growth, ion accumulation and photosynthetic parameters of Thellungiella halophila. J. Plant Physiol., v. 163, p. 1022-1031, 2006.

https://doi.org/10.1016/j.jplph.2005.07.015

MAHMOUDI, H.; HUANG, J.; GRUBER, M. Y.; KADDOUR, R.; LACHAÂL, M.; OUERGHI, Z.; HANNOUFA, A. The impact of genotype and salinity on physiological function, secondary metabolite accumulation, and antioxidative responses in lettuce. J. Agric. Food. Chem., v. 58, p. 5122-5130, 2010. https://doi.org/10.1021/jf904274v

MANSOUR, M.; SALAMA, K.; ALI, F.; AND HADID, A. Cell and plant responses to $\mathrm{NaCl}$ in Zea mays L. cultivars differing in salt tolerance. Gen. Appl. Plant Physiol., v. 31, p. 29-41, 2005.

MELONI, D. A.; OLIVA, M. A.; MARTINEZ, C. A.; CAMBRAIA, J. Photosynthesis and activity of superoxide dismutase, peroxidise and glutathione reductase in cotton under salt stress. Environ. Exp. Bot., v. 49, p. 69-76, 2003. https://doi.org/10.1016/S0098-8472(02)00058-8

MESSEDI, D.; LABIDI, N.; GRIGNON, C.; AND ABDELLY, C. Limits imposed by salt to the growth of the halophyte Sesuvium portulacastrum. J. plant. nutr. Soil. sci. v. 167, p. 720-725, 2004.

https://doi.org/10.1002/jpln.200420410

MISRA, N.; DWIVEDI, U. N. Genotypic difference in salinity tolerance of greengram cultivars. Plant. Sci., v. 166, p. 1135-1142, 2004. https://doi.org/10.1016/j.plantsci.2003.11.028

MORADI KOR N, DIDARSHETABAN MB, AND SAEID HR."Fenugreek (Trigonella foenum-graecum L.) as a valuable medicinal plant."International journal of Advanced Biologicaland Biomedical Research 1 (2013): 922-931.

MUNNS, R.; PASSIOURA, J. B. Hydraulic resistance of plants. III. Effects of $\mathrm{NaCl}$ in barley and lupin. Aust. J. plant. physiol., v. 11, p. 351-359, 1984. https://doi.org/10.1071/PP9840351

NAVARRO, J. M.; FLORES, P.; GARRIDO, C.; AND MARTINEZ, V. Changes in the contents of antioxidant compounds in pepper fruits at ripening stages, as affected by salinity. Food Chemistry, v. 96, p. 66-73, 2006. https://doi.org/10.1016/j.foodchem.2005.01.057

OERTLI, J. J. Extra cellular salt accumulation, a possible mechanism of salt injury in plants. Agrochimica, v. 12, p. 461-469, 1968. 
OUESLATI, S.; KARRAY, B. N.; ATTIA, H.; RABHI, M.; KSOURI, R.; AND LACHAAL, M. Physiological and antioxidant responses of Mentha pulegium (Pennyroyal) to salt stress. Acta Physiol. Plant, v. 32, p. 289296, 2010. https://doi.org/10.1007/s11738-009-0406-0

PAPADOPOULOS, A.; FOTIADIS, D. I.; COSTARIDOU, L. Improvement of microcalcification cluster detection in mammography utilizing image enhancement techniques. Computers in Biology and Medicine, v. 38, n. 10, p. 1045-1055. 2008. https://doi.org/10.1016/j.compbiomed.2008.07.006

PETROPOULOS, G. A. Fenugreek - The genus Trigonella. Taylor and Francis, London and New York, 2002. https://doi.org/10.4324/9780203217474

PINHEIRO, C.; CHAVES, M. M. Photosynthesis and drought: can we make metabolic connections from available data? J. Exp. Bot., v. 62, p. 869-882, 2011. https://doi.org/10.1093/jxb/erq340

PITZSCHKE, A.; AND HIRT, H. Mitogen-activated protein kinases and reactive oxygen species signaling in plants. Plant. Physiol., v. 141, v. 351-356, 2006.

POLLE, A. Defense against photooxidative damage in: Scandalios J. Oxidative stress and the molecular biology of antioxidant defenses. Cold Spring Harbor Laboratory Press NY. p. 785-813, 1997.

PRIETO, P.; PINEDA, M.; AGUILAR, M. Spectrophotometric quantitation of antioxidant capacity through the formation of a phosphomolybdenum complex: specific application to the determination of vitamin E. Anal. Biochem., v. 269, p. 337-341, 1999. https://doi.org/10.1006/abio.1999.4019

QURESHI, M. I.; ISRAR, M.; ABDIN, M. Z.; IQBAL, M. Responses of Artemisia annua L. to lead and saltinduced oxidative stress. Environ. Exp. Bot., v. 53, p. 185-193, 2005.

https://doi.org/10.1016/j.envexpbot.2004.03.014

RAGHAVAN, S. Handbook of spices, seasonings, and flavorings. Boca Raton: CRC. Taylor and Francis Group, 2007.

SATO, F. K.; NISHIDA, K.; YAMADA, Y. Activities of carboxylation enzymes and products of ${ }^{14} \mathrm{CO}_{2}$ fixation in photoautotrophically cultured cells. Plant Sci. Lett., v. 20, p. 91-97, 1980.

https://doi.org/10.1016/0304-4211(80)90027-9

SCANDALIOS, J. G. Oxidative stress: Molecular perception and transduction of signals triggering antioxidant gene defenses. Braz J Med Biol Res., v. 38, p. 995-1014, 2005. https://doi.org/10.1590/S0100879X2005000700003

SHAO, X.; BAI, N; HE, K; HO, C. T; YANG, C. S; SANG, S. Apple polyphenols, phloretin and phloridzin: New trapping agents of reactive dicarbonyl species. Chem Res Toxicol., v. 21 pp. 2042-2050, 2008. https://doi.org/10.1021/tx800227v

SHARMA, P.; JHA, AB.; DUBEY, RS.; PESSARAKLI, M. Reactive oxygen species, oxidative damage, and antioxidative defense mechanism in plants under stressful conditions. J Bot. 2012.

https://doi.org/10.1155/2012/217037

SILVEIRA, J.; ARAÚJO, S.; LIMA, J.; AND VIÉGAS, R. A. Roots and leaves display contrasting osmotic adjustment mechanisms in response to $\mathrm{NaCl}$-salinity in Atriplex nummularia. Environ. Exp. Bot., v. 66, p. 18, 2009.

SINGLETON, V. L.; ORTHOFER, R.; LAMUELA-RAVENTOS, R. M. Analysis of total phenols and other oxidation substrates and antioxidants by means of folin-ciocalteu reagent. Methods Enzymology, v. 299, p. 152-178, 1999. https://doi.org/10.1016/S0076-6879(99)99017-1 
SOUSSI, M.; OCAÑA, A.; AND LIUCH, C. Effects of salt stress on growth, photosynthesis and nitrogen fixation in chick-pea (Cicer arietinum L.). J. Exp. Bot. v. 49, p. 1329-1337, 1998.

https://doi.org/10.1093/jxb/49.325.1329

SPEER, M.; KAISER, W. M. Ion relations of symplastic and apoplastic space in leaves from Spinacia oloraceae L. and Pisum sativum L. under salinity. Plant. Physiol. v. 97, p. 990-997, 1991.

https://doi.org/10.1104/pp.97.3.990

SUDHAKAR, C.; LAKSHMI, A.; GIRIDARAKUMAR, S. Changes in the antioxidant enzyme efficacy in two high yielding genotypes of mulberry (Morus alba L.) under $\mathrm{NaCl}$ salinity. Plant. Sci., v. 161, p. 613-619, 2001. https://doi.org/10.1016/S0168-9452(01)00450-2

TONON, G.; KEVERS, C.; AIVRE-RAMPANT, O.; GRAZIANI, M.; AND GASPAR, T. Effect of NaCl and mannitol iso-osmotic stresses on proline and free polyamine levels in embryogenic Fraxinus angustifolia callus. J. Plant Physiol., v. 161, p. 701-708, 2004. https://doi.org/10.1078/0176-1617-01096

TURAN, M. A.; KATKAT, A. V.; TABAN, S. V. Ariations in proline, chlorophyll and mineral elements contents of wheat plants grown under salinity stress. J. Agron., v. 6, p. 137-141, 2007 b.

https://doi.org/10.3923/ja.2007.137.141

TUTEJA, N.; GILL, S. S.; TUTEJA, R.; Omics and Plant Stress Tolerance Bentham Science

Publisher, USA, pp. 39-64. 2011.

ZHISHEN, J.; MENGCHENG, T.; AND JIANMING, W. The determination of flavonoid contents in mulberry and their scavenging effects on superoxide radicals. Food Chemistry, v. 64, p. 555-559, 1999. https://doi.org/10.1016/S0308-8146(98)00102-2

ZOROV, D. B.; JUHASZOVA, M.; SOLLOTT, S. J. Mitochondrial reactive oxygen species (ROS) and ROSinduced ROS release. Physiol Rev., v. 94, 909-950. 2014. https://doi.org/10.1152/physrev.00026.2013 